The original version published March 9, 2005, contained errors.

The corrected version was published November 16, 2006.

\title{
Characterization of the FKBP•rapamycin॰FRB Ternary Complex
}

\section{Supporting Information}

\author{
Laura A. Banaszynski ${ }^{\perp}$, Corey W. Liu ${ }^{\varsigma}$, Thomas J. Wandless ${ }^{+*}{ }^{*}$ \\ ${ }^{\perp}$ Department of Chemistry, Stanford University, Stanford, CA 94305 \\ ${ }^{\varsigma}$ Stanford Magnetic Resonance Laboratory, Stanford University, Stanford, CA 94305 \\ * Department of Molecular Pharmacology, Stanford University, Stanford, CA 94305
}

\section{SUPPORTING FIGURES}

Figure S1

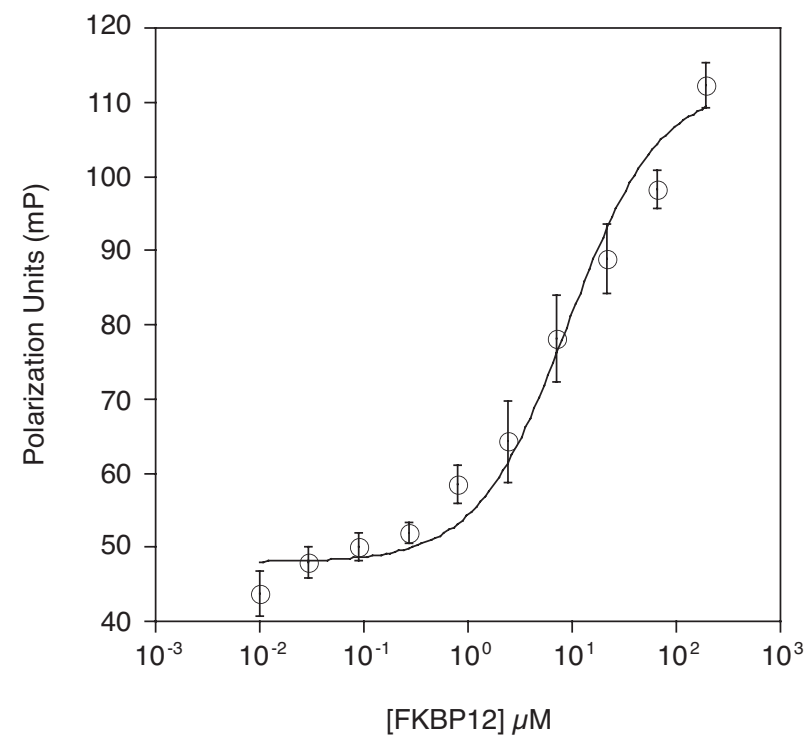

Figure S1. A saturation binding experiment using fluorescence polarization quantitates the affinity of $10 \mathrm{nM}$ Fl-rap for various concentrations of FKBP $(0.01 \mu \mathrm{M}$ to $245 \mu \mathrm{M})$. Modification of rapamycin at the C40-cyclohexyl hydroxyl group clearly does not abrogate Fl-rap's interactions with FKBP, although the observed dissociation constant $\left(K_{\mathrm{d}}\right.$ $\geq 10 \mu \mathrm{M})$ is considerably weaker than that of unmodified rapamycin $\left(K_{\mathrm{d}}=0.2 \mathrm{nM}\right)$. 


\section{Chart S1. Chemical structure of FI-SLF.}

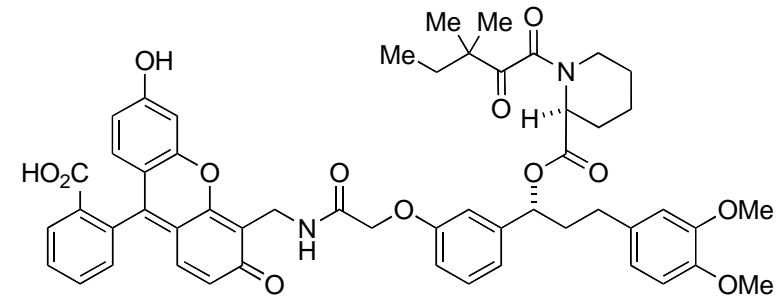

Figure S2

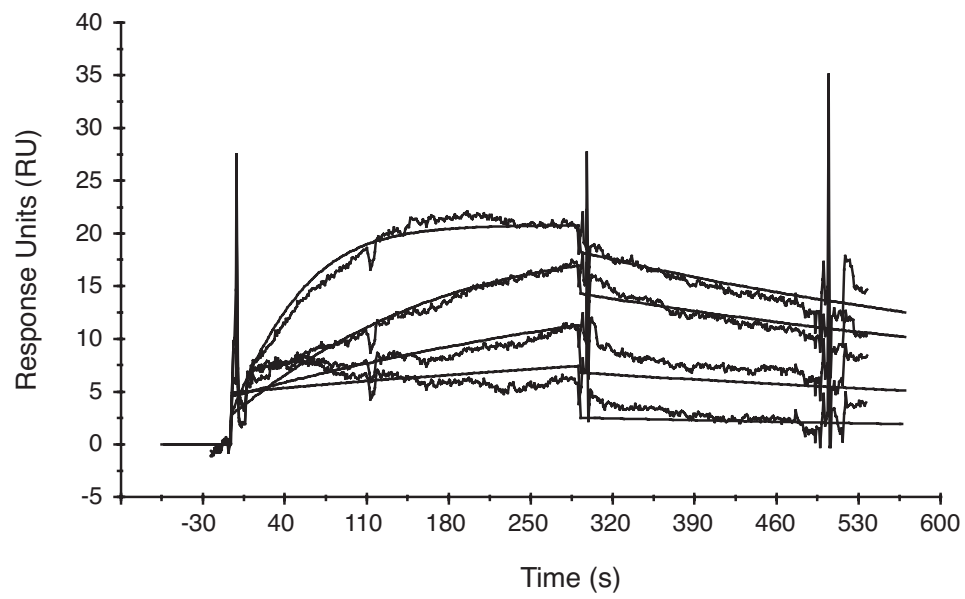

Figure S2. SPR analysis of the GST-FKBP•rapamycin dissociation constant. A GSTFKBP surface was titrated with various concentrations of rapamycin $(0.16 \mathrm{nM}, 0.47 \mathrm{nM}$, $1.4 \mathrm{nM}$, and $4.2 \mathrm{nM}$ ). Figure shows a representative data set. Kinetic fit indicates a GST-FKBP•rapamycin dissociation constant of $0.27 \mathrm{nM}\left(\mathrm{k}_{\mathrm{a}}=5.8 \times 10^{6} \mathrm{M}^{-1} \cdot \mathrm{sec}^{-1}, \mathrm{k}_{\mathrm{d}}=\right.$ $\left.1.6 \times 10^{-3} \mathrm{sec}^{-1}\right)$. 


\section{Figure S3}

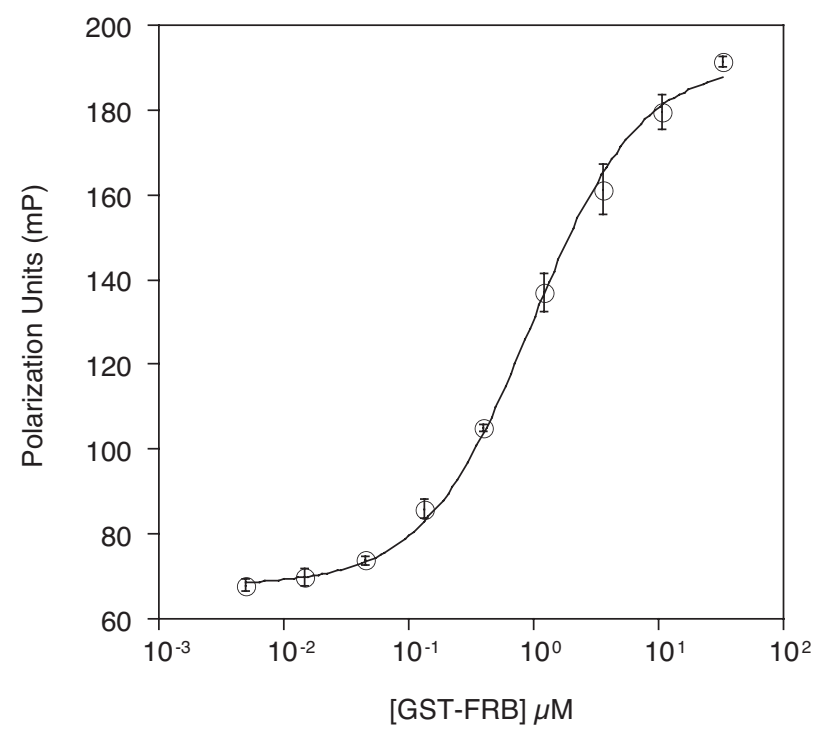

Figure S3. Fluorescence polarization assay. A saturation binding experiment between $10 \mathrm{nM}$ Fl-rap and various concentrations of GST-FRB $(0.005 \mu \mathrm{M}$ to $32 \mu \mathrm{M})$ indicates a dissociation constant of $960 \pm 69 \mathrm{nM}$. This is comparable to the affinity of Fl-rap for the isolated FRB domain $\left(\mathrm{K}_{\mathrm{d}}=490 \pm 39 \mathrm{nM}\right)$.

Chart S2. Chemical structure of Biotin-LC-LC-rapamycin.

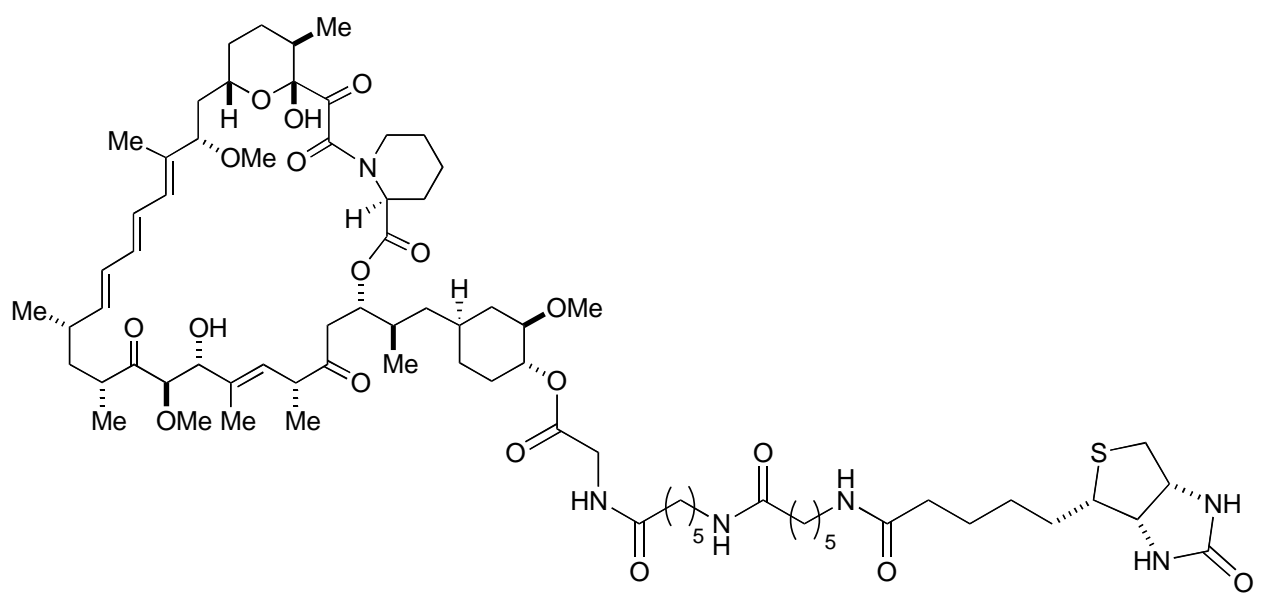




\section{Figure S4}
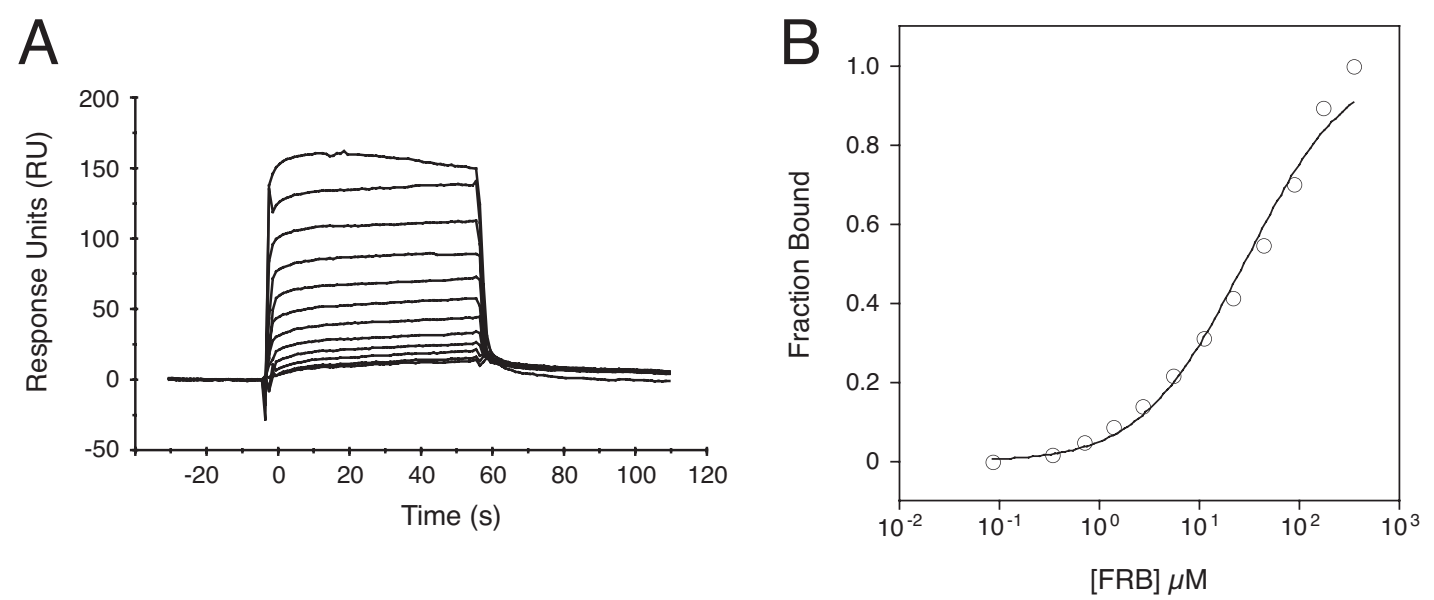

Figure S4. SPR analysis of the rapamycin $\bullet F R B$ interaction. (A) A representative data set. Data shown is the response of the biotin-LC-LC-rapamycin surface to various concentrations of FRB $(0.085 \mu \mathrm{M}$ to $350 \mu \mathrm{M})$. (B) An equilibrium binding analysis provides a rapamycin $\bullet \mathrm{FRB}$ dissociation constant of $23 \pm 3.5 \mu \mathrm{M}$.

\section{Figure S5}
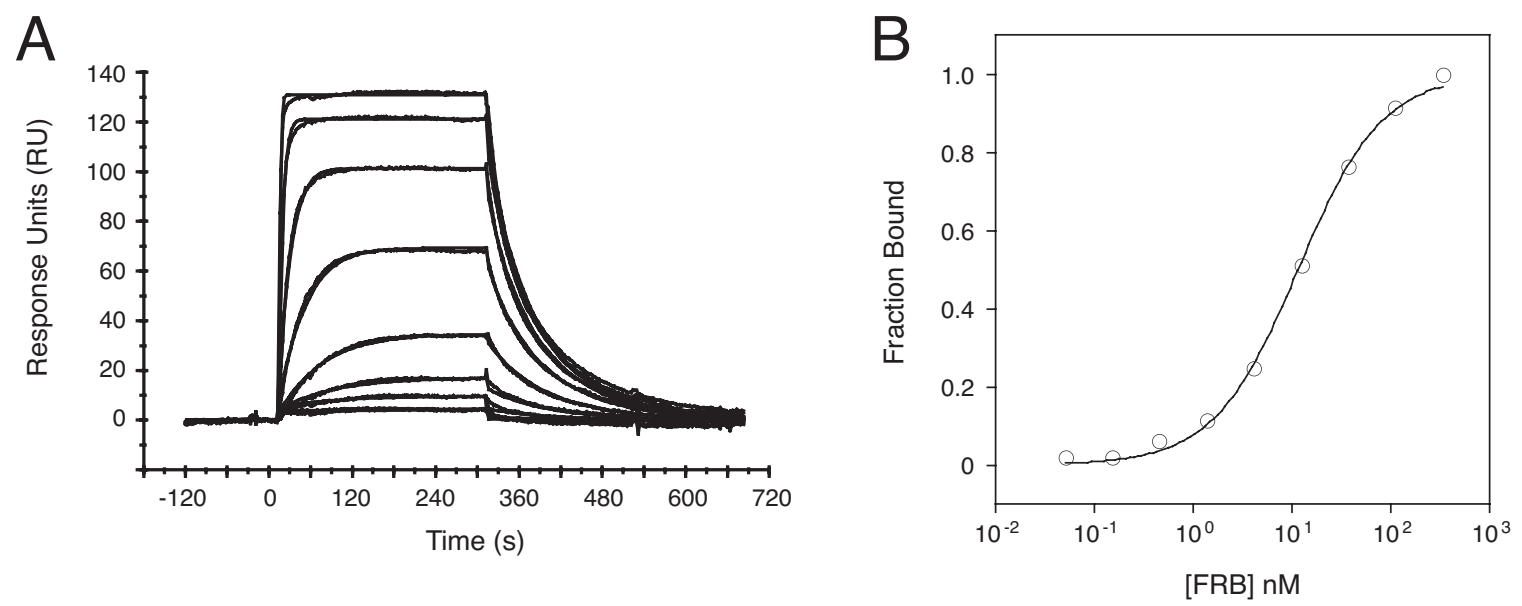

Figure S5. SPR analysis of the GST-FKBP•rapamycin secondary dissociation constant for FRB. A GST-FKBP•rapamycin surface was titrated with various concentrations of FRB (0.05 nM to $330 \mathrm{nM})$. Figure shows a representative data set in which each curve has reached steady state. (A) Kinetic fit indicates a GST-FKBP•rapamycin $\bullet F R B$ secondary dissociation constant of $11 \mathrm{nM}\left(\mathrm{k}_{\mathrm{a}}=1.7 \times 10^{6} \mathrm{M}^{-1} \cdot \mathrm{sec}^{-1}, \mathrm{k}_{\mathrm{d}}=1.9 \times 10^{-2} \mathrm{sec}^{-1}\right)$. (B) An equilibrium binding analysis gives a GST-FKBP•rapamycin॰FRB secondary dissociation constant of $12 \mathrm{nM}$. 


\section{Figure S6}

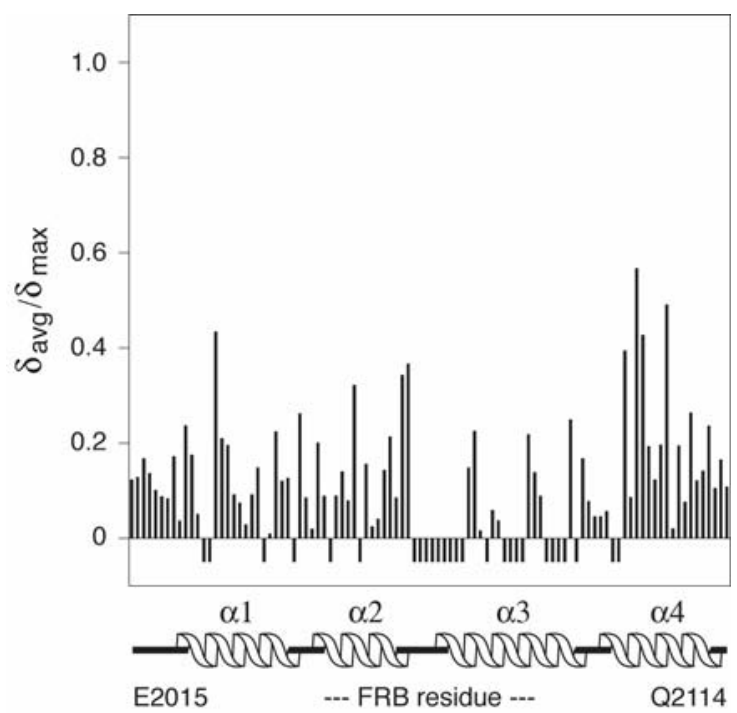

Figure S6. Rapamycin was added to the mixture of TMOP-rapamycin and FRB and changes in the backbone ${ }^{1} \mathrm{H}$ and ${ }^{15} \mathrm{~N}$ amide chemical shifts of FRB are shown. Chemical shift perturbations are visualized as normalized weighted average shift differences, $\delta_{\mathrm{avg}} / \delta_{\max }$ (see materials and methods). All chemical shifts normalized to the residue that exhibited that greatest perturbation in chemical shift during the rapamycin-FRB titration (F2039). 


\section{CHEMICAL SYNTHESIS}

Experimental Procedures. All reactions were carried out in flame-dried glassware sealed with a rubber septum under a nitrogen atmosphere. Liquids and solutions were transferred via syringe. Tetrahydrofuran and dichloromethane were purified using an alumina-based solvent purification system. Diisopropylethylamine and pyridine were distilled over calcium hydride. DMSO stored over $4 \AA \AA$ molecular sieves and anhydrous DMF in AcroSeal bottles were used without further purification. Flash chromatography was carried out using ICN silica gel 32-63 (230-400 mesh). Analytical thin layer chromatography (TLC) was performed using EM $0.25 \mathrm{~mm}$ silica gel $60 \mathrm{~F}_{254}$ glass plates. TLC plates were visualized using UV fluorescence and by one or more of the following: ceric ammonium molybdate, potassium permanganate and ninhydrin. ${ }^{1} \mathrm{H}$ NMR spectra were recorded on a $500 \mathrm{MHz}$ spectrometer and are reported in ppm using solvent resonance as an internal standard $\left(\mathrm{CHCl}_{3}=7.26 \mathrm{ppm}, \mathrm{CD}_{2} \mathrm{HOD}=3.31 \mathrm{ppm}\right)$. Data are reported as $\delta$ shift $(\mathrm{s}=$ singlet, $\mathrm{d}=$ doublet, $\mathrm{t}=$ triplet, $\mathrm{q}=$ quartet, $\mathrm{m}=$ multiplet, $\mathrm{br}=$ broad, $J=$ coupling constant in $\mathrm{Hz}$, integration). Rapamycin exists as a 3:1 mixture of trans:cis amide rotamers. Only the major rotamer is reported. Proton decoupled ${ }^{13} \mathrm{C}$ NMR spectra were recorded on a $500 \mathrm{MHz}$ spectrometer and are reported in ppm using the solvent resonance as an internal standard $\left(\mathrm{CDCl}_{3}=77.0 \mathrm{ppm}\right)$.

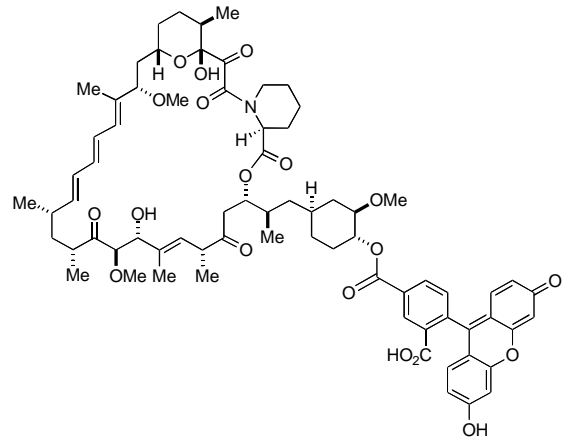

C40-(5-Carboxyfluorescein)-rapamycin (Fl-rap). 5-Carboxyfluorescein (41.2 $\mathrm{mg}, 109.4 \mu \mathrm{mol}, 1$ equiv) was dissolved in DMF $(750 \mu \mathrm{L})$ and stirred at $-20{ }^{\circ} \mathrm{C}$. Pyridine was added $(19.5 \mu \mathrm{L}, 240.7 \mu \mathrm{mol}$, 2.2 equiv), followed by trichlorobenzyl chloride (17.1 $\mu \mathrm{L}, 109.4 \mu \mathrm{mol}, 1$ equiv). The reaction mixture was covered with aluminum foil and stirred at $-20{ }^{\circ} \mathrm{C}$ for $1 \mathrm{~h}$ to allow formation of the mixed anhydride. Rapamycin (100 mg, $109.4 \mu \mathrm{mol}, 1$ equiv) and 4-(dimethylamino)pyridine (14.7 $\mathrm{mg}$,

$120.3 \mu \mathrm{mol}, 1.1$ equiv) were dissolved in DMF and added dropwise. The reaction was warmed to ambient temperature and stirred overnight. The reaction was diluted with water and extracted with ethyl acetate three times. The organic layers were combined, washed with brine, dried over anhydrous sodium sulfate, and concentrated. Purification over silica gel (20/1 chloroform/methanol) followed by reverse-phase HPLC purification $(\mathrm{Rt}=13$ min Waters Xterra M8 phenyl, $1 \mathrm{~mL} / \mathrm{min}, 70 \%$ methanol/water containing $0.05 \%$ trifluoroacetic acid $50{ }^{\circ} \mathrm{C}$ ) provided $4 \mathrm{mg}$ ( $3 \%$ yield) of the desired product as a yellow solid. ${ }^{1} \mathrm{H}$ NMR $\left(500 \mathrm{MHz}, \mathrm{CD}_{3} \mathrm{OD}\right) \delta 8.59(\mathrm{~s}, 1 \mathrm{H}), 8.40(\mathrm{~d}, J=8.0 \mathrm{~Hz}, 1 \mathrm{H})$, $7.34(\mathrm{~d}, J=7.7 \mathrm{~Hz}, 1 \mathrm{H}), 6.69$ (d, $J=2.2 \mathrm{~Hz}, 4 \mathrm{H}), 6.60$ (d, $J=7.6 \mathrm{~Hz}, 2 \mathrm{H}), 6.54$ (dd, $J$ = 8.6, $2.4 \mathrm{~Hz}, 2 \mathrm{H}), 6.47(\mathrm{dd}, J=14.6,11.0 \mathrm{~Hz}, 1 \mathrm{H}), 6.30(\mathrm{dd}, J=14.5,10.6 \mathrm{~Hz}, 1 \mathrm{H})$, $6.19(\mathrm{dd}, J=14.9,10.7 \mathrm{~Hz}, 1 \mathrm{H}), 6.13(\mathrm{~d}, J=9.9 \mathrm{~Hz}, 1 \mathrm{H}), 5.48(\mathrm{dd}, J=14.6,9.5 \mathrm{~Hz}, 1$ H), $5.25(\mathrm{~d}, J=10.3 \mathrm{~Hz}, 1 \mathrm{H}), 5.14(\mathrm{~m}, 1 \mathrm{H}), 5.09(\mathrm{~d}, J=5.1 \mathrm{~Hz}, 1 \mathrm{H}), 4.06(\mathrm{~d}, J=5 \mathrm{~Hz}$, $1 \mathrm{H}), 3.69(\mathrm{~m}, 3 \mathrm{H}), 3.56(\mathrm{~m}, 1 \mathrm{H}), 3.49(\mathrm{~m}, 1 \mathrm{H}), 3.44(\mathrm{~s}, 3 \mathrm{H}), 3.35(\mathrm{~s}, 3 \mathrm{H}), 3.32(\mathrm{~m}, 2$ H), $3.15(\mathrm{~s}, 3 \mathrm{H}), 2.91(\mathrm{~m}, 1 \mathrm{H}), 2.85(\mathrm{~d}, J=16.5 \mathrm{~Hz}, 1 \mathrm{H}), 2.60(\mathrm{~m}, 1 \mathrm{H}), 2.48$, (dd, $J=$ 17.6, $8.8 \mathrm{~Hz}, 1 \mathrm{H}), 2.32-1.45(\mathrm{~m}, 14 \mathrm{H}), 1.86,(\mathrm{~s}, 3 \mathrm{H}), 1.62(\mathrm{~s}, 3 \mathrm{H}), 1.05(\mathrm{~d}, J=6.6 \mathrm{~Hz}$, $3 \mathrm{H}), 1.00(\mathrm{~d}, J=6.5 \mathrm{~Hz}, 3 \mathrm{H}), 0.96(\mathrm{~d}, J=6.5 \mathrm{~Hz}, 3 \mathrm{H}), 0.92(\mathrm{~d}, J=6.7 \mathrm{~Hz}, 3 \mathrm{H}), 0.86$ (d, $J=6.8 \mathrm{~Hz}, 3 \mathrm{H})$. TLC $R_{f}=0.63(20 \%$ methanol in chloroform). MS calculated for $\mathrm{C}_{72} \mathrm{H}_{89} \mathrm{NO}_{19}(\mathrm{M}+\mathrm{Na}):$ 1295, found (ESI): 1295. 
но ${ }^{\text {N }} \mathrm{N}_{3}$ Azidoacetic acid. Sodium azide (147 mg, $2.3 \mathrm{mmol}, 2.1$ equiv) was suspended in DMSO $(6.25 \mathrm{~mL})$ and stirred at ambient temperature for $1.5 \mathrm{~h}$ to give a clear yellow solution. Bromoacetic acid (149 mg, $1.1 \mathrm{mmol}, 1$ equiv) was dissolved in DMSO and added dropwise, upon which the solution turned clear orange. After $12 \mathrm{~h}$, the reaction was diluted with water $(5 \mathrm{~mL})$ and acidified using concentrated hydrochloric acid $(1 \mathrm{~mL})$. The aqueous solution was then extracted with ethyl acetate three times. The organic layers were combined, washed with brine, dried over anhydrous sodium sulfate, and concentrated to give $91.9 \mathrm{mg}$ ( $85 \%$ yield) of the desired product as a pale yellow oil. ${ }^{1} \mathbf{H}$ NMR $\left(500 \mathrm{MHz}, \mathrm{CDCl}_{3}\right) \delta 3.75(\mathrm{~s}, 2 \mathrm{H}) .{ }^{13} \mathbf{C}$ NMR $\left(125 \mathrm{MHz}, \mathrm{CDCl}_{3}\right) \delta$ 49.89, 170.13. MS calculated for $\mathrm{C}_{2} \mathrm{H}_{3} \mathrm{~N}_{3} \mathrm{O}_{2}$ (M-): 100, found (ESI): 100 .

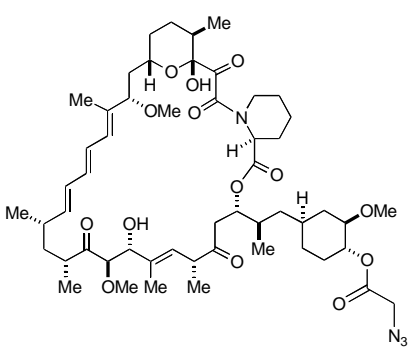

C40-Azidoacetyl-rapamycin. Azidoacetic acid (14.2 mg, $140.6 \mu \mathrm{mol}, 1.1$ equiv) was dissolved in THF $(700 \mu \mathrm{L})$ and stirred at $-20{ }^{\circ} \mathrm{C}$. Triethylamine was added $(27 \mu \mathrm{L}, 191.7$ $\mu \mathrm{mol}, 1.5$ equiv), followed by trichlorobenzyl chloride $(22 \mu \mathrm{L}$, $140.6 \mu \mathrm{mol}, 1.1$ equiv). The reaction mixture was stirred at $20{ }^{\circ} \mathrm{C}$ for $1 \mathrm{~h}$ to allow formation of the mixed anhydride. Rapamycin (117 mg, $127.8 \mu \mathrm{mol}, 1$ equiv) and 4(dimethylamino)pyridine (17.2 $\mathrm{mg}, 140.6 \mu \mathrm{mol}, 1.1$ equiv) were dissolved in THF and added dropwise. The reaction was warmed to ambient temperature and stirred for $2 \mathrm{~h}$. The reaction was diluted with saturated sodium bicarbonate $(1 \mathrm{~mL})$ and extracted with ethyl acetate three times. The organic layers were combined, washed with brine, dried over anhydrous sodium sulfate, and concentrated. Purification over silica gel (3/1 hexanes/ethyl acetate) provided $55.8 \mathrm{mg}$ ( $44 \%$ yield) of the desired product as a white solid. ${ }^{1} \mathbf{H}$ NMR $\left(500 \mathrm{MHz}, \mathrm{CDCl}_{3}\right) \delta 6.38(\mathrm{dd}, J=14.8$, $10.7 \mathrm{~Hz}, 1 \mathrm{H}), 6.30(\mathrm{dd}, J=14.9,10.3 \mathrm{~Hz}, 1 \mathrm{H}), 6.13(\mathrm{dd}, J=15.1,10.3 \mathrm{~Hz}, 1 \mathrm{H}), 5.96$ $(\mathrm{d}, J=10.6 \mathrm{~Hz}, 1 \mathrm{H}), 5.53(\mathrm{dd}, J=15.1,8.8 \mathrm{~Hz}, 1 \mathrm{H}), 5.40(\mathrm{~d}, J=9.9 \mathrm{~Hz}, 1 \mathrm{H}), 5.28(\mathrm{~d}, J$ $=5.0 \mathrm{~Hz}, 1 \mathrm{H}), 5.16(\mathrm{q}, J=5.4 \mathrm{~Hz}, 1 \mathrm{H}), 4.76(\mathrm{~m}, 2 \mathrm{H}), 4.17(\mathrm{~d}, J=5.9 \mathrm{~Hz}, 1 \mathrm{H}), 3.86$, $(\mathrm{m}, 1 \mathrm{H}), 3.73(\mathrm{~d}, J=5.9 \mathrm{~Hz}, 1 \mathrm{H}), 3.66,(\mathrm{q}, J=7.9 \mathrm{~Hz}, 1 \mathrm{H}), 3.56(\mathrm{br} \mathrm{d}, J=13.9 \mathrm{~Hz}$, 1H), $3.41(\mathrm{~m}, 1 \mathrm{H}), 3.37(\mathrm{~m}, 1 \mathrm{H}), 3.36(\mathrm{~s}, 3 \mathrm{H}), 3.32(\mathrm{~s}, 3 \mathrm{H}), 3.18(\mathrm{~m}, 1 \mathrm{H}), 3.13(\mathrm{~s}, 3$ H), $2.83(\mathrm{~m}, 1 \mathrm{H}), 2.71(\mathrm{dd}, J=16.7,5.6 \mathrm{~Hz}, 1 \mathrm{H}), 2.71(\mathrm{~m}, 1 \mathrm{H}), 2.57$ (dd, $J=16.8,6.4$ $\mathrm{Hz}, 1 \mathrm{H}) .2 .34(\mathrm{~m}, 1 \mathrm{H}), 2.32(\mathrm{~m}, 1 \mathrm{H}), 2.08-1.45(\mathrm{~m}, 11 \mathrm{H}), 1.74(\mathrm{~s}, 3 \mathrm{H}), 1.62(\mathrm{~s}, 3 \mathrm{H})$, $1.09(\mathrm{~d}, J=6.7 \mathrm{~Hz}, 3 \mathrm{H}), 1.04(\mathrm{~d}, J=6.6 \mathrm{~Hz}, 3 \mathrm{H}), 0.98(\mathrm{~d}, J=6.5 \mathrm{~Hz}, 3 \mathrm{H}), 0.94(\mathrm{~d}, J=$ $6.6 \mathrm{~Hz}, 3 \mathrm{H}), 0.90(\mathrm{~d}, J=6.8 \mathrm{~Hz}, 3 \mathrm{H}), 0.83(\mathrm{~m}, 1 \mathrm{H})$. TLC $R_{f}=0.62(60 \%$ ethyl acetate in hexanes). MS calculated for $\mathrm{C}_{53} \mathrm{H}_{80} \mathrm{~N}_{4} \mathrm{O}_{14}$ (M-): 996, found (ESI): 996. HRMS calculated for $\mathrm{C}_{53} \mathrm{H}_{80} \mathrm{~N}_{4} \mathrm{O}_{14}(\mathrm{M}+\mathrm{Na}): 1019.5569$, found (ESI): 1019.5549 .

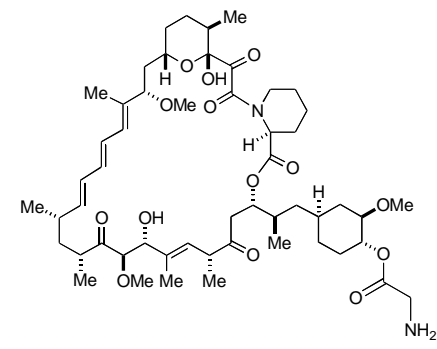

C40-Glycyl-rapamycin. C40-Azidoacetyl-rapamycin (26.9 $\mathrm{mg}, 27.0 \mu \mathrm{mol}, 1$ equiv) and recrystalized triphenylphosphine (6.4 mg, $24.3 \mu \mathrm{mol}, 0.9$ equiv) were dissolved in 3:1 $\mathrm{THF} / \mathrm{H}_{2} \mathrm{O}(240 \mu \mathrm{L})$ and stirred at ambient temperature under a nitrogen atmosphere. The reaction mixture became cloudy and yellow. At $3 \mathrm{~h}$, the reaction was diluted with water (1 $\mathrm{mL})$ and extracted with ethyl acetate three times. The organic layers were combined, washed with brine, dried over anhydrous sodium sulfate, and concentrated. Purification over silica gel (40/1 chloroform/methanol) provided $21 \mathrm{mg}(80 \%$ yield $)$ of the desired product as a white 
solid. ${ }^{1} \mathbf{H}$ NMR $\left(500 \mathrm{MHz}, \mathrm{CDCl}_{3}\right) \delta 6.38(\mathrm{dd}, J=14.6,10.6 \mathrm{~Hz}, 1 \mathrm{H}), 6.31$, (dd, $J=$ $15.1,10.3 \mathrm{~Hz}, 1 \mathrm{H}), 6.14(\mathrm{dd}, J=15.1,10.3 \mathrm{~Hz}, 1 \mathrm{H}), 5.96(\mathrm{~d}, J=11.0 \mathrm{~Hz}, 1 \mathrm{H}), 5.55$ $(\mathrm{dd}, J=15.3,8.8 \mathrm{~Hz}, 1 \mathrm{H}), 5.41(\mathrm{~d}, J=10.1 \mathrm{~Hz}, 1 \mathrm{H}), 5.28(\mathrm{~d}, J=5.5 \mathrm{~Hz}, 1 \mathrm{H}), 5.17$ (m, $1 \mathrm{H}), 4.72(\mathrm{~m}, 2 \mathrm{H}), 4.18(\mathrm{~d}, J=6.0 \mathrm{~Hz}, 1 \mathrm{H}), 3.87(\mathrm{~m}, 1 \mathrm{H}), 3.74(\mathrm{~d}, J=5.9 \mathrm{~Hz}, 1 \mathrm{H})$, 3.67 (q, $J=7.4 \mathrm{~Hz}, 1 \mathrm{H}), 3.57$ (br d, $J=14.8 \mathrm{~Hz}, 1 \mathrm{H}), 3.43(\mathrm{~m}, 1 \mathrm{H}), 3.37$ (s, $3 \mathrm{H}), 3.36$ (m, $1 \mathrm{H}), 3.33(\mathrm{~s}, 3 \mathrm{H}), 3.25(\mathrm{~m}, 1 \mathrm{H}), 3.14(\mathrm{~s}, 3 \mathrm{H}), 2.72$ (dd, $J=16.5,5.3 \mathrm{~Hz}, 1 \mathrm{H}), 2.71$ (m, $1 \mathrm{H}), 2.58(\mathrm{dd}, J=17.0,6.3 \mathrm{~Hz}, 1 \mathrm{H}), 2.34(\mathrm{~m}, 1 \mathrm{H}), 2.31(\mathrm{~m}, 1 \mathrm{H}), 2.08-1.45$ (m, 11 H), $1.75(\mathrm{~s}, 3 \mathrm{H}), 1.65(\mathrm{~s}, 3 \mathrm{H}), 1.09(\mathrm{~d}, J=6.7 \mathrm{~Hz}, 3 \mathrm{H}), 1.05(\mathrm{~d}, J=6.6 \mathrm{~Hz}, 3 \mathrm{H}), 0.99$ $(\mathrm{d}, J=6.5 \mathrm{~Hz}, 3 \mathrm{H}), 0.95(\mathrm{~d}, J=6.6 \mathrm{~Hz}, 3 \mathrm{H}), 0.91(\mathrm{~d}, J=6.8 \mathrm{~Hz}, 3 \mathrm{H}), 0.86(\mathrm{~m}, 1 \mathrm{H})$. TLC $R_{f}=0.33\left(10 \%\right.$ methanol in chloroform). MS calculated for $\mathrm{C}_{53} \mathrm{H}_{82} \mathrm{~N}_{2} \mathrm{O}_{14}(\mathrm{M}+\mathrm{H})$ : 972, found (ESI): 972.

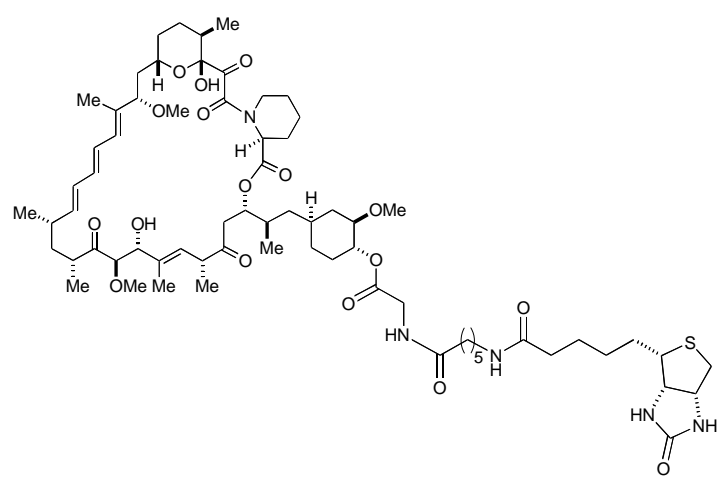

Biotin-LC-rapamycin. C40-Glycylrapamycin (23.9 $\mathrm{mg}, 24.6 \mu \mathrm{mol}, 1$ equiv), $\mathrm{N}-(+)$-biotinyl-aminohexanoic-acid $\quad(10.6$ mg, $29.5 \mu \mathrm{mol}, 1.2$ equiv), and PyBOP (19.2 mg, $36.9 \mu \mathrm{mol}, 1.5$ equiv) were dissolved in DMF and stirred at ambient temperature. Diisopropylethylamine (8.6 $\mu \mathrm{L}, 49.2 \mu \mathrm{mol}, 2$ equiv) was added and the reaction was allowed to stir for $1 \mathrm{~h}$. At this time, an additional 0.5 equiv PyBOP and 0.75 equiv diisopropylethylamine were added, and the reaction was allowed to stir overnight. The reaction was diluted with $\mathrm{pH}$ 2.2 phosphate buffer $(1 \mathrm{~mL})$ and extracted with ethyl acetate three times. The organic layers were combined, washed with brine, dried over anhydrous sodium sulfate, and concentrated. Purification over silica gel (20/1 chloroform/methanol) provided $19.1 \mathrm{mg}$ (59\% yield) of the desired product as a white solid. ${ }^{\mathbf{1}} \mathbf{H} \mathbf{~ N M R}\left(500 \mathrm{MHz}, \mathrm{CDCl}_{3}\right) \delta 7.79$ (br s, 1 H), 7.59 (br s, 1 H), 6.93 (br s, 1 H), 6.37 (dd, $J=14.6,10.9$ Hz, 1 H), 6.28 (dd, $J$ $=14.6,10.5 \mathrm{~Hz}, 1 \mathrm{H}), 6.11(\mathrm{dd}, J=15.0,10.6 \mathrm{~Hz}, 1 \mathrm{H}), 6.00(\mathrm{~d}, J=11.0 \mathrm{~Hz}, 1 \mathrm{H}), 5.49$ $(\mathrm{dd}, J=14.7,9.2 \mathrm{~Hz}, 1 \mathrm{H}), 5.35(\mathrm{~d}, J=10.3 \mathrm{~Hz}, 1 \mathrm{H}), 5.24(\mathrm{~d}, J=4.9 \mathrm{~Hz}, 1 \mathrm{H}), 5.14(\mathrm{~m}$, $1 \mathrm{H}), 4.31(\mathrm{~m}, 1 \mathrm{H}), 4.05(\mathrm{~d}, J=6.1 \mathrm{~Hz}, 1 \mathrm{H}), 3.96(\mathrm{~m}, 1 \mathrm{H}), 3.69(\mathrm{~d}, J=6.6 \mathrm{~Hz}, 1 \mathrm{H})$, $3.63(\mathrm{~m}, 1 \mathrm{H}), 3.52(\mathrm{~m}, 1 \mathrm{H}), 3.35(\mathrm{~m}, 1 \mathrm{H}), 3.35(\mathrm{~s}, 3 \mathrm{H}), 3.32(\mathrm{~s}, 3 \mathrm{H}), 3.26(\mathrm{~m}, 1 \mathrm{H})$, $3.22(\mathrm{dd}, J=9.6,6.3 \mathrm{~Hz}, 1 \mathrm{H}), 3.14-3.10(\mathrm{~m}, 1 \mathrm{H}), 3.13(\mathrm{~s}, 3 \mathrm{H}), 2.90(\mathrm{~m}, 1 \mathrm{H}), 2.72(\mathrm{~d}, J$ $=12.0 \mathrm{~Hz}, 1 \mathrm{H}), 2.66(\mathrm{dd}, J=17.9,5.6 \mathrm{~Hz}, 1 \mathrm{H}), 2.66(\mathrm{~m}, 1 \mathrm{H}), 2.49(\mathrm{dd}, J=17.0,7.3$ $\mathrm{Hz}, 1 \mathrm{H}), 2.31(\mathrm{t}, J=7.4 \mathrm{~Hz}, 2 \mathrm{H}), 2.26(\mathrm{t}, J=6.8 \mathrm{~Hz}, 2 \mathrm{H}), 2.20(\mathrm{~m}, 1 \mathrm{H}), 2.04(\mathrm{~m}, 1 \mathrm{H})$, $1.89(\mathrm{dd}, J=13.3,6.3 \mathrm{~Hz}, 1 \mathrm{H}), 1.92-1.32(\mathrm{~m}, 22 \mathrm{H}), 1.79(\mathrm{~s}, 3 \mathrm{H}), 1.65(\mathrm{~s}, 3 \mathrm{H}), 1.05$ (d, $J=6.5 \mathrm{~Hz}, 3 \mathrm{H}), 1.02(\mathrm{~d}, J=6.5 \mathrm{~Hz}, 3 \mathrm{H}), 0.96-0.89(\mathrm{~m}, 9 \mathrm{H})$. TLC $R_{f}=0.51(20 \%$ methanol in chloroform). MS calculated for $\mathrm{C}_{69} \mathrm{H}_{107} \mathrm{~N}_{5} \mathrm{O}_{17} \mathrm{~S}$ (M-): 1309, found (ESI): 1309. HRMS calculated for $\mathrm{C}_{69} \mathrm{H}_{107} \mathrm{~N}_{5} \mathrm{O}_{17} \mathrm{~S}(\mathrm{M}+\mathrm{Na})$ : 1332.7280, found (ESI): 1332.7274 . 


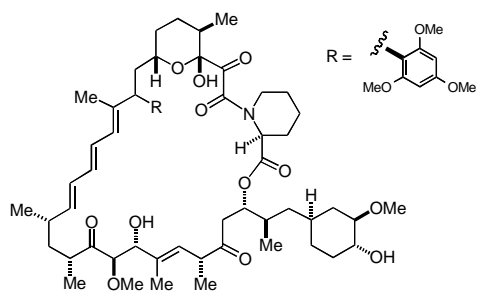

TMOP-rapamycin. Rapamycin $(24.6 \mathrm{mg}, 26.9 \mu \mathrm{mol}, 1$ equiv) was dissolved in $2 \mathrm{~mL}$ dichloromethane and cooled to $-40{ }^{\circ} \mathrm{C}$. Trifluoroacetic acid $(0.2 \mathrm{~mL}, 2.6$ mmol, 100 equiv) was added, upon which the solution turned bright yellow, and the reaction was allowed to stir at $-40{ }^{\circ} \mathrm{C}$ for $30 \mathrm{~min}$. Trimethoxybenzene $(106 \mathrm{mg}, 630$ $\mu$ mol, 25 equiv) was dissolved in $2 \mathrm{~mL}$ dichloromethane and added, upon which the solution turned reddish brown. After 30 minutes, $5 \mathrm{~mL}$ saturated sodium bicarbonate was cooled to $0{ }^{\circ} \mathrm{C}$ and added to the reaction flask. The reaction mixture was extracted with ethyl acetate three times. The organic layers were combined, washed with brine, dried over anhydrous sodium sulfate, concentrated, and loaded unto a silica gel column. Excess trimethoxybenzene was eluted with 2/1 hexanes/ethyl acetate, followed by elution with $1 / 3$ to obtain $20.5 \mathrm{mg}$ ( $73 \%$ yield) of the desired product as a white solid. All spectral properties matched literature values. ${ }^{1}$

\footnotetext{
${ }^{1}$ Luengo, J.I.; Yamashita, D. S.; Dunnington, D.; Beck, A. K.; Rozamus, L.W.; Yen, H-K.; Bossard, M. J.; Levy, M. A.; Hand, A,; Newman-Tarr, T.; Badger, A.; Faucette, L.; Johnson, R. K.; D’Alessio, K.; Porter, T.; Shu, A. Y. L.; Heys, R.; Choi, J.; Kongsaeree, P.; Clardy, J.; Holt, D. A. Chem. Biol. 1995, 2, 471-481.
} 
Banaszynski et al. • page S10

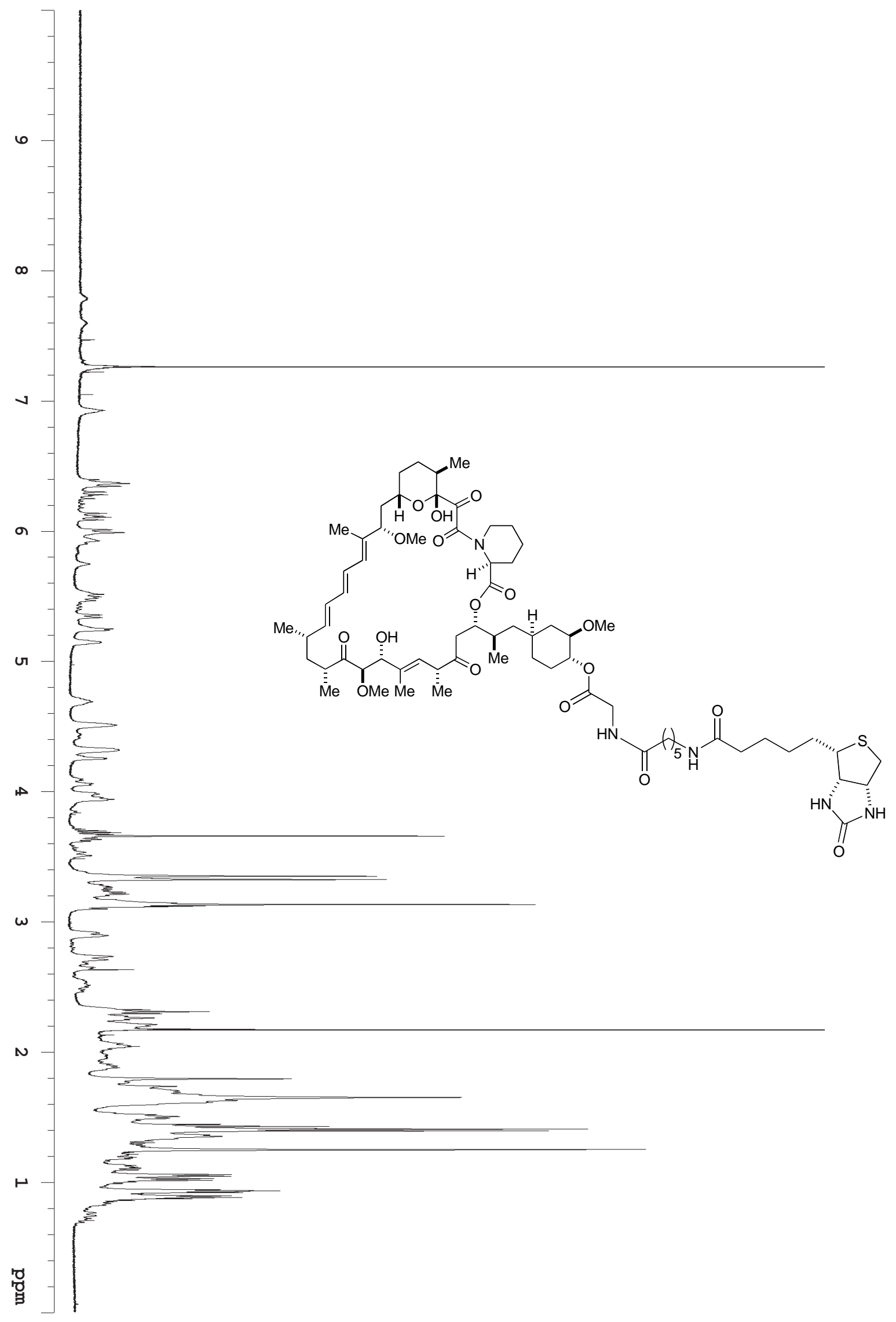


Banaszynski et al. • page S11

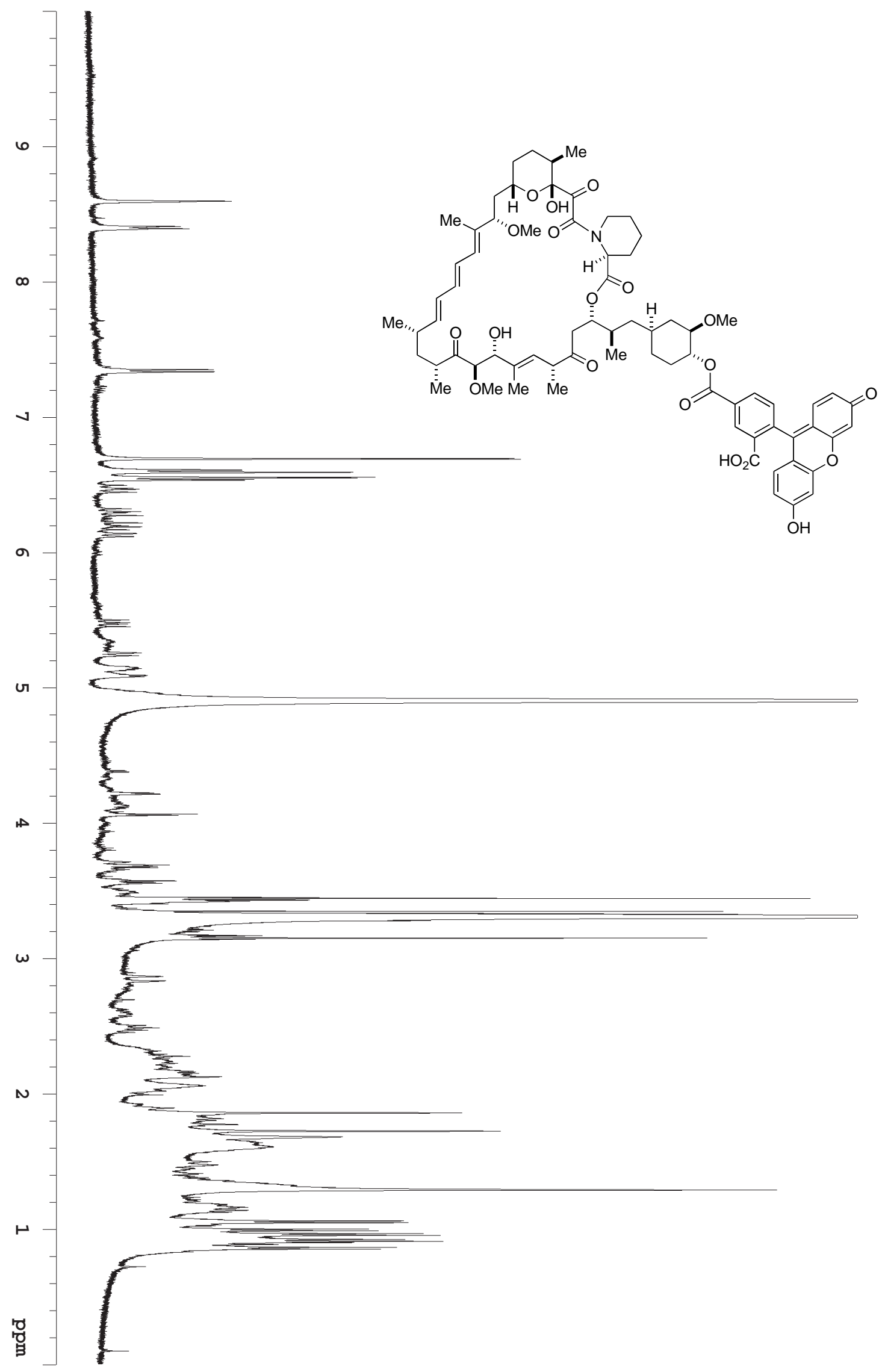




\section{PROTEIN PRODUCTION}

Experimental Procedures. All assays were performed with P20, P200, and P1000 Gilson pipetmen that were calibrated every 12 months. All buffers were made with deionized Milli-Q water and analytical grade reagents. SDS-Polyacrylamide Gel Electrophoresis (SDS-PAGE) was run with the Bio-Rad Mini-Protean III system and 29:1 acrylamide:bis-acrylamide. Absorbance measurements were performed on a Hewlett-Packard 8453 UV-Vis spectrophometer.

Expression and Purification of FKBP. A pET-11b plasmid containing the FKBP sequence was transformed into E. coli BL21 (DE3) cells and plated on Luria Bertani (LB) agar plates with ampicillin (Amp). A single colony was picked from the plate and used to inoculate a $100-\mathrm{mL} \mathrm{LB} / \mathrm{Amp}$ overnight culture. After $12 \mathrm{~h}$ incubation at $37^{\circ} \mathrm{C}$, $15 \mathrm{~mL}$ of the overnight culture was used to inoculate a Fernbach flask containing $1.5 \mathrm{~L}$ $\mathrm{LB} / \mathrm{Amp}$ media. The culture was incubated at $37^{\circ} \mathrm{C}$ with shaking until $\mathrm{OD}_{600} \sim 0.5(2 \mathrm{~h})$, at which point protein expression was induced by the addition of $0.4 \mathrm{mM}$ isopropyl- $\beta$ thiogalactopyranoside (IPTG). After $5 \mathrm{~h}$, the cells were harvested by centrifugation (JA$10,5 \mathrm{~K}, 4{ }^{\circ} \mathrm{C}, 20 \mathrm{~min}$ ) and the cell pellets were stored at $-80^{\circ} \mathrm{C}$ overnight.

The cells were thawed on ice and resuspended in $30 \mathrm{~mL}$ lysis buffer $(20 \mathrm{mM}$ TRIS, 5 $\mathrm{mM}$ BME, $\mathrm{pH}$ 8.0). A Branson sonicator with a microtip probe was used to sonicate the bacteria on ice (power $=50 \%, 3 \times 2 \mathrm{~min}, 2 \mathrm{~min}$ rest). Cell lysates were clarified by centrifugation (JA-25.5, 17K, $4{ }^{\circ} \mathrm{C}, 30 \mathrm{~min}$ ), and then loaded at $5 \mathrm{~mL} / \mathrm{min}$ onto a DE52 anion exchange column, which had been equilibrated in lysis buffer. The column was run using lysis buffer at $2 \mathrm{~mL} / \mathrm{min}$, collecting $8 \mathrm{~mL}$ fractions.

Fractions 3-7 were determined by SDS-PAGE to contain the most concentrated protein. Fractions were concentrated using Millipore Amicon Centrifugal Filter Devices, $10 \mathrm{kDa}$ cut-off (swing bucket rotor, $4 \mathrm{~K}, 4{ }^{\circ} \mathrm{C}$ ), and loaded onto a Sephacryl S-200 sizing column, which had been pre-equilibrated in running buffer (20 mM TRIS, $150 \mathrm{mM} \mathrm{NaCl}, \mathrm{pH} 7.2$ ). The column was run at $2 \mathrm{~mL} / \mathrm{min}$, and $8 \mathrm{~mL}$ fractions were collected. Fractions 27-34 were identified as containing FKBP by SDS-PAGE, and were resubjected to sizing column purification. Fractions $24-30$ were determined to be $95 \%$ pure by SDS-PAGE, and were concentrated to $16 \mathrm{~mL}$. Protein concentration was determined by $\mathrm{A}_{280}(\varepsilon=$ $9860 \mathrm{M}^{-1} \mathrm{~cm}^{-1}$ ) to be $420 \mu \mathrm{M}$. Aliquots were flash frozen in liquid $\mathrm{N}_{2}$ and stored at -80 ${ }^{\circ} \mathrm{C}$.

Expression and Purification of FRB. pGEX-2T-FRB was obtained from Prof. Jie Chen (Univ. of Illinois). E. coli BL21 cells were transformed with the plasmid and plated on LB/Amp plates. A single colony was picked from the plate and used to inoculate a 100$\mathrm{mL} \mathrm{LB} /$ Amp overnight culture. After $12 \mathrm{~h}$ incubation at $37^{\circ} \mathrm{C}$, the incubator was cooled to $30^{\circ} \mathrm{C}$, and $15 \mathrm{~mL}$ of overnight culture was used to inoculate each of two Fernbach flasks containing $1.5 \mathrm{~L} \mathrm{LB} / \mathrm{amp}$. The cultures were incubated at $30{ }^{\circ} \mathrm{C}$ with shaking until $\mathrm{OD}_{600} \sim 0.5(3 \mathrm{~h})$, at which point the temperature was lowered to $25^{\circ} \mathrm{C}$, and expression was induced by adding IPTG to a final concentration of $0.4 \mathrm{mM}$. After $6-7 \mathrm{~h}$, the cells were harvested by centrifugation (JA-10, $5 \mathrm{~K}, 4{ }^{\circ} \mathrm{C}, 20 \mathrm{~min}$ ), and the cell pellets were resuspended in $60 \mathrm{~mL}$ lysis buffer (PBS pH 7.4, $500 \mu \mathrm{g} / \mathrm{mL}$ lysozyme) and frozen at -20 ${ }^{\circ} \mathrm{C}$ overnight. 
The cell suspensions were thawed at ambient temperature for $2 \mathrm{~h}$. A Branson sonicator with a microtip probe was used to sonicate the bacteria on ice (power $=60 \%, 4 \times 10 \mathrm{sec}$, $10 \mathrm{sec}$ rest). Cell lysates were clarified by centrifugation (JA-25.5, $17 \mathrm{~K}, 4{ }^{\circ} \mathrm{C}, 30 \mathrm{~min}$ ). The supernatant was batch loaded for $2 \mathrm{~h}$ at $4{ }^{\circ} \mathrm{C}$ onto a glutathione sepharose resin that had been equilibrated in PBS pH 7.4. After several washes with PBS pH 7.4, the resin was loaded onto a Bio-Rad disposable column, and the protein was eluted with $50 \mathrm{mM}$ TRIS, $10 \mathrm{mM}$ glutathione, $\mathrm{pH}$ 7.2. Bradford-positive fractions were pooled, and the GST affinity tag was removed from GST-FRB by cleavage with thrombin. The dialysis solution was dialyzed against 1L 10x PBS pH 7.4 for $1 \mathrm{~h}$ at ambient temperature and then dialyzed against 3L 1x PBS pH 7.4 at ambient temperature overnight. The extent of cleavage was monitored by SDS-PAGE.

The cleaved protein was purified on a Sephacryl S-200 sizing column in PBS pH 7.4. Fractions deemed pure by SDS-PAGE were combined and concentrated using Millipore Amicon Centrifugal Filter Devices, $10 \mathrm{kDa}$ cut-off (swing bucket rotor, $4 \mathrm{~K}, 4{ }^{\circ} \mathrm{C}$ ) to a concentration of approximately $100 \mu \mathrm{M}$. FRB concentration was determined by $\mathrm{A}_{280}(\varepsilon=$ $\left.18683 \mathrm{M}^{-1} \mathrm{~cm}^{-1}\right)$. Aliquots $(1 \mathrm{~mL})$ were stored at $4{ }^{\circ} \mathrm{C}$, with a lifetime of approximately 6-8 weeks.

\section{Expression and Purification of GST-FKBP Fusion Protein. A pGEX-2T-FKBP} plasmid was also obtained from Jie Chen. GST-FKBP was prepared as above, and extensively dialyzed against PBS pH 7.4 after elution from the glutathione sepharose resin. Fusion protein concentration was determined by Bradford assay analysis.

Expression and Purification of Isotopically Labeled FRB. Isotopically labeled ${ }^{15} \mathrm{~N}$ FRB was prepared in the same manner as described above with the exception of being grown in M9 minimal media with ${ }^{15} \mathrm{NH}_{4} \mathrm{Cl}$ as the sole nitrogen source. Isotopically labeled ${ }^{13} \mathrm{C} /{ }^{15} \mathrm{~N}$ FRB was prepared in M9 minimal media with ${ }^{15} \mathrm{NH}_{4} \mathrm{Cl}$ as the sole nitrogen source and $\mathrm{U}_{-}{ }^{13} \mathrm{C}_{6}$-glucose as the sole carbon source. Purified proteins were dialyzed into NMR buffer (20 mM PBS pH 6.8, 10\% $\left.\mathrm{D}_{2} \mathrm{O}\right)$ and stored at $4{ }^{\circ} \mathrm{C}$.

\section{FLUORESCENCE POLARIZATION}

Experimental Procedures. All assays were performed with P20, P200, and P1000 Gilson pipetmen that were calibrated every 12 months. All buffers were made with deionized Milli-Q water and analytical grade reagents. Fluorescence polarization measurements were performed on an LJL Biosystems Analyst AD 96-384 instrument using a continuous lamp source and fluorescein filters (excitation $=485 \mathrm{~nm}$, emission $=$ $530 \mathrm{~nm}$, beamsplitter $=505 \mathrm{~nm}$ ). Competition data was modeled in Mathematica and the best fit was determined through Pearson's $R^{2}$ value in Excel.

Quantitative Mathematical Modeling of Competition Binding Assays. The systems described in this paper can be quite complicated at equilibrium. In the competition binding assay used to determine the FKBP•rapamycin dissociation constant, the solution may contain monomeric species (FLSLF, FKBP, and rapamycin), and heterodimeric species (FKBP•FLSLF and FKBP•rapamycin). The system becomes even more 
complicated with the addition of FRB, where a solution at equilibrium may contain monomeric species (Fl-rap, FKBP, FRB, and rapamycin), dimeric species $(\mathrm{FKBP} \bullet$ rapamycin, rapamycin $\bullet \mathrm{FRB}$, and Fl-rap•FRB), and trimeric species (FKBP•rapamycin•FRB), wherein primary dissociation constants must be decoupled from secondary dissociation constants.

For example, the FKBP•rapamycin complex is described by a primary dissociation constant, FKBP $K_{d} 1$, because FKBP is the first protein to bind to rapamycin. Likewise, the binding of the rapamycin $\cdot \mathrm{FRB}$ complex to FKBP is described by a secondary dissociation constant, FKBP $K_{\mathrm{d}} 2$, as FKBP is the second protein binding to rapamycin. In order to decouple these interactions, we developed a mathematical model that explicitly considers all species present at equilibrium using ratios of rate constants for association and dissociation of all possible complexes and a corresponding collection of partial differential rate equations. ${ }^{2}$ The theoretical binding isotherms generated are then evaluated against the experimental data using Pearson's coefficient of determination $\left(R^{2}\right)$. Below are the partial differential equations solved in order to determine dissociation constants for the given interactions.

\section{rapamycin + FRB (Fig. $2 B$ - triangles)}

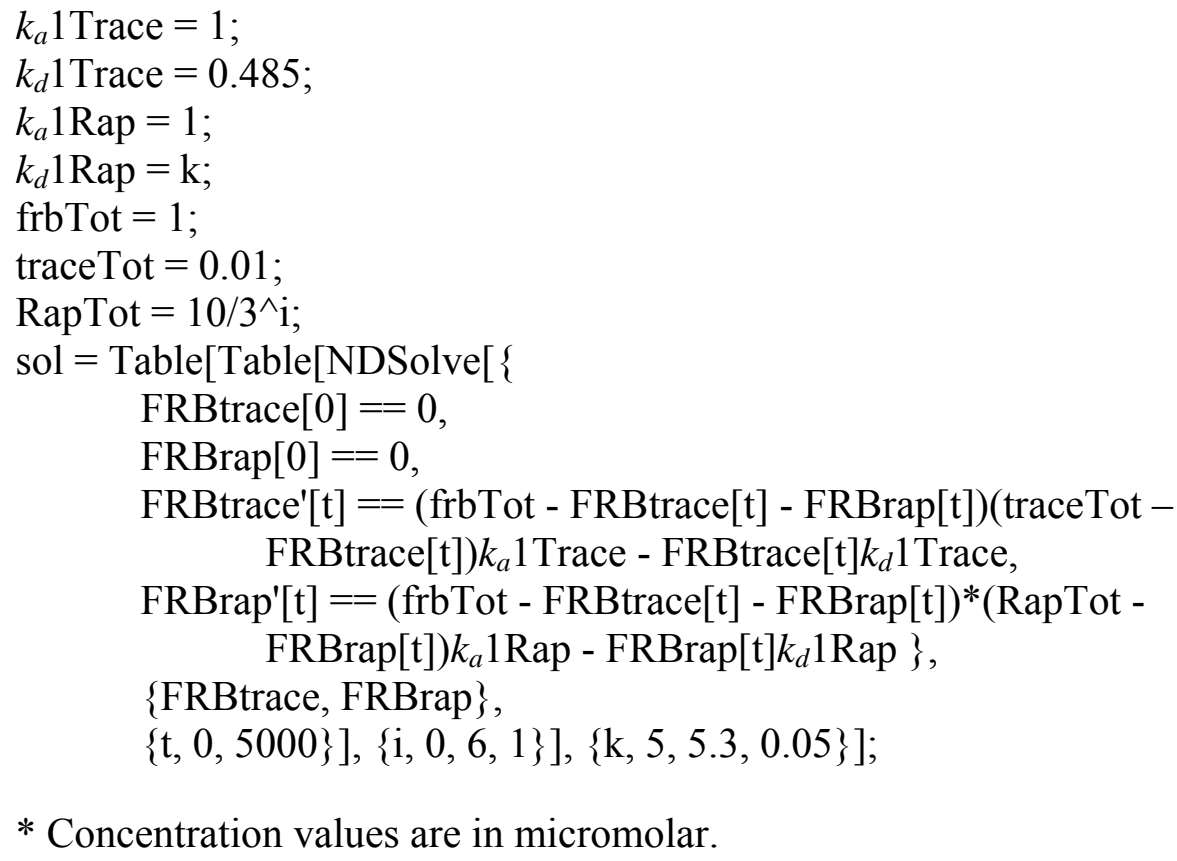

* Concentration values are in micromolar.

2 Braun, P. D.; Wandless, T. J. Biochem. 2004, 43, 5406-5413. 
FKBP orapamycin + FRB (Fig. $2 B-$ circles)

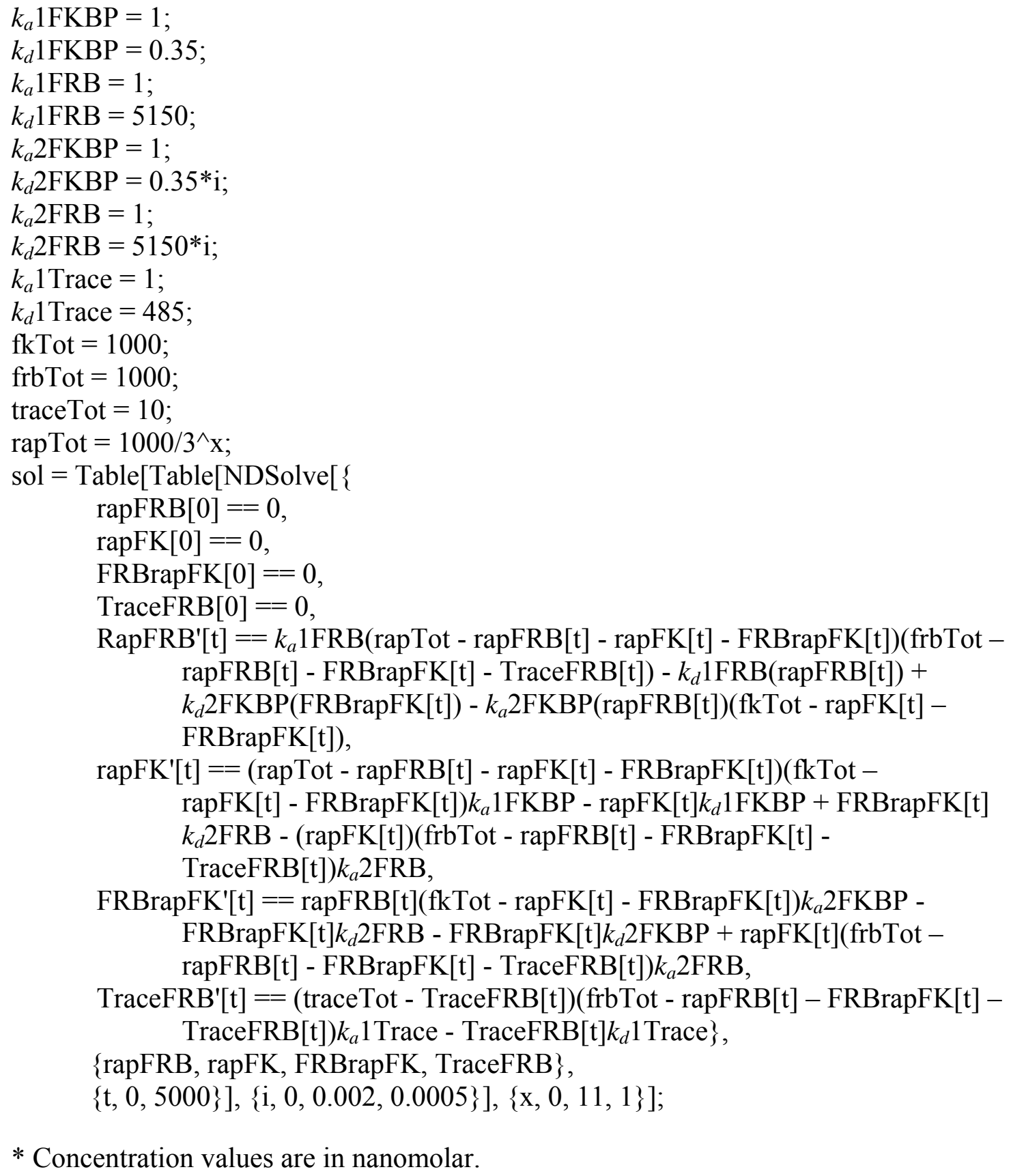

* Concentration values are in nanomolar. 
FKBP + rapamycin (Fig. 2C)

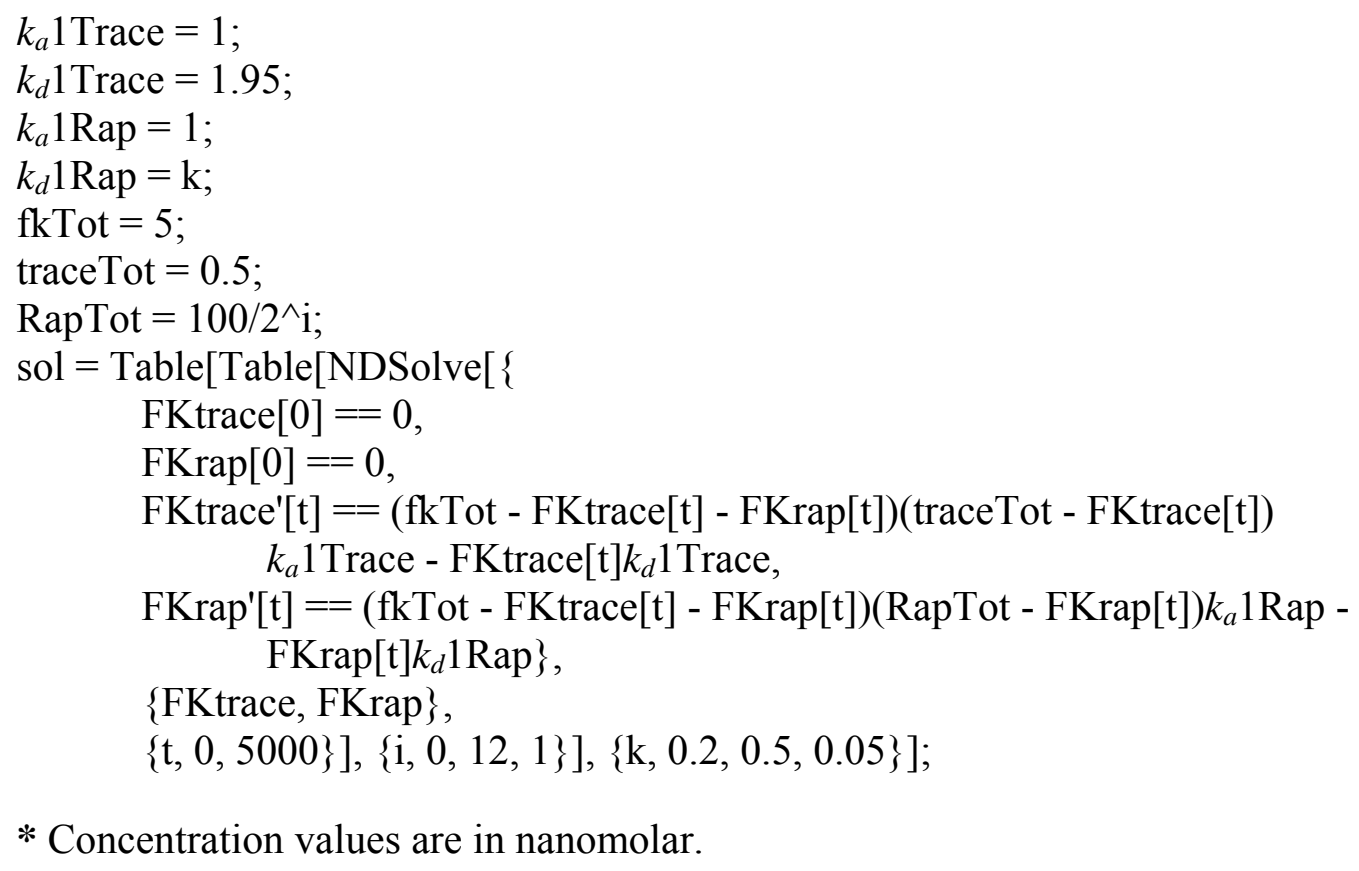

* Concentration values are in nanomolar.

\section{SURFACE PLASMON RESONANCE}

Experimental Procedures. All assays were performed with P20, P200, and P1000 Gilson pipetmen that were calibrated every 12 months. All buffers were made with deionized Milli-Q water and analytical grade reagents. All buffers were 0.22 PES filtered and degassed for 20 minutes before use. Surface plasmon resonance measurements were performed on a Biacore 3000 instrument. Instrument was desorbed weekly, sanitized monthly, and serviced annually. Standard EDC/NHS amine coupling was used to immobilize proteins to a CM5 surface. The surface was activated with an EDC/NHS solution ( $200 \mu \mathrm{M}$ and $50 \mu \mathrm{M}$, respectively) at $5 \mu \mathrm{L} / \mathrm{min}$ for $15 \mathrm{~min}$. Protein was immobilized as described in the Experimental Methods, and unreacted NHS-activated acids were quenched with a $15 \mathrm{~min}$. injection of $1.0 \mathrm{M}$ ethanolamine at $5 \mu \mathrm{L} / \mathrm{min}$. 


\section{NUCLEAR MAGNETIC RESONANCE}

Experimental Procedures. ${ }^{15} \mathrm{~N}-\mathrm{NOESY}-\mathrm{HSQC}$, HNCACB and CBCACONH threedimensional spectra were acquired on ${ }^{13} \mathrm{C} /{ }^{15} \mathrm{~N}-\mathrm{FRB}(600 \mu \mathrm{M}$ in $250 \mu \mathrm{L}$ in Shigemi symmetrical microtube, $20 \mathrm{mM}$ PBS, pH 6.8, 10\% $\mathrm{D}_{2} \mathrm{O}$ ) on Varian 600 and $800 \mathrm{MHz}$ Inova spectrometers. All experiments were acquired at $25^{\circ} \mathrm{C}$, and both spectrometers were running VNMR v6.1C. Spectra were processed with VNMR and analyzed utilizing Sparky (Goddard, T. D.; Kneller, D. G. SPARKY 3, University of California, San Francisco.). The sequential assignment of FRB follows:

$\begin{array}{ccccc}\text { residue } & \text { C-alpha } & \text { C-beta } & { }^{15} \mathrm{~N} & { }^{1} \mathrm{H}-\mathrm{N} \\ \text { G1 } & --- & -- & --- & --- \\ \text { S2 } & 59.056 & 64.353 & -- & -- \\ \text { E2015 } & 57.480 & 30.428 & 123.200 & 8.781 \\ \text { L2016 } & 55.775 & 42.865 & 123.059 & 8.235 \\ \text { I2017 } & 61.401 & 39.097 & 122.560 & 8.060 \\ \text { R2018 } & 56.383 & 31.535 & 126.047 & 8.379 \\ \text { V2019 } & 62.597 & 33.539 & 122.166 & 8.191 \\ \text { A2020 } & 52.920 & 19.831 & 127.846 & 8.393 \\ \text { I2021 } & 61.560 & 40.091 & 119.362 & 8.245 \\ \text { L2022 } & 54.735 & 42.981 & 125.680 & 8.426 \\ \text { W2023 } & 61.316 & 29.141 & 125.016 & 9.479 \\ \text { H2024 } & 61.339 & 30.571 & 114.751 & 8.605 \\ \text { E2025 } & 59.438 & 30.484 & 119.862 & 6.608 \\ \text { M2026 } & --- & --- & 118.790 & 8.312 \\ \text { W2027 } & --- & --- & -- & --- \\ \text { H2028 } & 62.561 & 30.485 & -- & -- \\ \text { E2029 } & 59.652 & 30.421 & 116.514 & 8.136 \\ \text { G2030 } & 47.302 & \text { N/A } & 107.112 & 8.319 \\ \text { L2031 } & 58.730 & 42.455 & 120.799 & 8.830 \\ \text { E2032 } & 60.916 & 30.064 & 121.425 & 7.957 \\ \text { E2033 } & 59.190 & 29.760 & 120.701 & 7.791 \\ \text { A2034 } & 56.278 & 18.838 & 120.902 & 9.318 \\ \text { S2035 } & 61.775 & 63.136 & 112.734 & 8.373 \\ \text { R2036 } & --- & --- & 123.969 & 7.606 \\ \text { L2037 } & 58.556 & --- & -- & --- \\ \text { Y2038 } & 61.964 & --- & 117.509 & 8.388 \\ \text { F2039 } & 61.365 & 38.506 & 116.811 & 8.560 \\ \text { G2040 } & 47.246 & \text { N/A } & 107.574 & 7.717 \\ \text { E2041 } & -- & --- & 117.069 & 7.272 \\ \text { R2042 } & 57.089 & 27.256 & -- & --- \\ \text { N2043 } & 51.560 & 38.499 & 118.564 & 8.478 \\ \text { V2044 } & 66.753 & 32.612 & 124.001 & 8.097 \\ \text { K2045 } & 60.465 & 32.873 & 120.812 & 8.390 \\ \text { G2046 } & 48.140 & \text { N/A } & 105.922 & 8.092 \\ \text { M2047 } & 60.722 & 33.542 & 122.347 & 7.752 \\ \text { F2048 } & 61.313 & 38.550 & 118.574 & 8.419 \\ \text { E2049 } & 59.772 & 30.149 & 118.387 & 8.202 \\ \text { V2050 } & 65.359 & 32.854 & 117.306 & 7.506 \\ \text { L2051 } & 57.288 & 42.813 & 116.649 & 7.490 \\ \text { E2052 } & -- & --- & 120.235 & 8.605 \\ \text { P2053 } & 65.964 & 31.682 & --- & --- \\ \text { L2054 } & 57.431 & 39.670 & 119.586 & 6.760 \\ \text { H2055 } & 61.222 & 29.235 & 117.345 & 7.770 \\ \text { A2056 } & 55.961 & 18.539 & 122.626 & 8.442 \\ \text { M2057 } & 58.851 & 32.148 & 118.006 & 7.640 \\ \text { M2058 } & 56.927 & 32.140 & 115.617 & 7.158 \\ \text { E2059 } & 59.665 & 30.575 & 120.257 & 7.796 \\ \text { R2060 } & 58.461 & 30.620 & 116.811 & 7.655 \\ & & & & \end{array}$




\begin{tabular}{|c|c|c|c|c|}
\hline G2061 & --- & --- & 106.585 & 7.671 \\
\hline P2062 & --- & --- & --- & --- \\
\hline Q2063 & --- & --- & --- & --- \\
\hline T2064 & --- & --- & --- & --- \\
\hline L2065 & --- & --- & --- & --- \\
\hline K2066 & --- & --- & --- & --- \\
\hline E2067 & --- & --- & --- & --- \\
\hline T2068 & --- & --- & --- & --- \\
\hline S2069 & --- & --- & --- & --- \\
\hline F2070 & 62.683 & --- & --- & --- \\
\hline N2071 & 57.849 & 40.649 & 118.492 & 9.152 \\
\hline Q2072 & 59.180 & 29.060 & 118.888 & 8.721 \\
\hline A2073 & 55.029 & 18.518 & 119.952 & 7.410 \\
\hline Y2074 & 57.747 & 41.106 & 112.801 & 7.838 \\
\hline G2075 & 48.557 & N/A & 107.816 & 8.339 \\
\hline R2076 & --- & --- & 122.507 & 8.495 \\
\hline D2077 & --- & --- & --- & --- \\
\hline L2078 & --- & --- & --- & --- \\
\hline M2079 & --- & --- & --- & --- \\
\hline E2080 & 59.822 & 29.456 & --- & --- \\
\hline A2081 & 56.980 & 17.192 & 123.921 & 8.384 \\
\hline Q2082 & 60.034 & 28.081 & 117.342 & 7.890 \\
\hline E2083 & --- & --- & 120.542 & 7.850 \\
\hline W2084 & --- & --- & --- & --- \\
\hline C2085 & --- & --- & --- & --- \\
\hline R2086 & --- & --- & --- & --- \\
\hline K2087 & 61.018 & 32.588 & --- & --- \\
\hline Y2088 & 61.450 & 38.421 & 121.473 & 8.479 \\
\hline M2089 & 58.704 & 32.419 & 118.435 & 8.142 \\
\hline K2090 & 57.923 & 34.107 & 115.855 & 7.274 \\
\hline S2091 & 59.847 & 64.754 & 116.086 & 9.021 \\
\hline G2092 & 46.930 & N/A & 113.445 & 8.949 \\
\hline N2093 & 52.880 & 39.048 & 119.664 & 8.982 \\
\hline V2094 & 66.430 & 32.240 & 127.487 & 9.244 \\
\hline L2095 & --- & --- & 121.501 & 8.403 \\
\hline D2096 & 58.763 & 41.853 & --- & --- \\
\hline L2097 & 57.338 & 41.898 & 118.925 & 6.899 \\
\hline T2098 & 67.369 & 68.734 & 116.487 & 8.612 \\
\hline Q2099 & 59.151 & 27.556 & 120.012 & 7.409 \\
\hline A2100 & 56.559 & 20.074 & 120.721 & 7.366 \\
\hline W2101 & 62.173 & 29.728 & 116.011 & 8.551 \\
\hline D2102 & 58.526 & 40.765 & 121.131 & 8.387 \\
\hline L2103 & 58.545 & 43.466 & 120.940 & 7.035 \\
\hline Y2104 & 61.693 & 39.374 & 119.350 & 8.859 \\
\hline Y2105 & 61.630 & 37.874 & 117.762 & 9.643 \\
\hline H2106 & 60.191 & 30.986 & 120.071 & 7.726 \\
\hline V2107 & 67.859 & --- & 119.392 & 7.915 \\
\hline F2108 & 61.606 & 40.590 & 119.474 & 9.084 \\
\hline R2109 & 59.275 & 30.728 & 117.181 & 8.763 \\
\hline R2110 & 59.256 & 31.666 & 117.957 & 7.420 \\
\hline |2111 & 64.063 & 39.126 & 115.643 & 8.033 \\
\hline S2112 & 59.790 & 64.393 & 115.455 & 7.609 \\
\hline K2113 & 57.020 & 33.154 & 121.890 & 7.693 \\
\hline Q2114 & --- & --- & 126.427 & 7.874 \\
\hline
\end{tabular}

